\title{
ANALISIS KEBERHASILAN PENERAPAN E-LEARNING DI FAKULTAS TEKNIK UNIVERSITAS RIAU
}

\author{
ANALYSIS OF THE SUCCESS OF E-LEARNING APPLICATION \\ IN FACULTY OF ENGINEERING RIAU UNIVERSITY
}

\author{
Neni Seliana*), Arif Imam Suroso $^{* *}$, dan Lilik Noor Yuliati ${ }^{* * *}$ \\ *) Fakultas Teknik Universitas Riau \\ Simpang Baru, Tampan, Pekanbaru, Riau 28292, Indonesia \\ ${ }^{* *}$ Sekolah Bisnis, IPB University \\ Jl. Pajajaran Bogor 16151, Indonesia \\ ***) Departemen Ilmu Konsumen dan Keluarga, Fakultas Ekonomi Manusia, IPB University \\ Jl. Darmaga, Kampus IPB Darmaga, Bogor 16680, Indonesia
}

\begin{abstract}
E-learning is a learning system that uses information systems and internet and intranet technology. E-learning is one of the learning tools in the era of the technological revolution 4.0 which is one of the programs of the Ministry of Higher Education Research. Higher education institutions in Indonesia have used e-learning in learning activities. This study aims to evaluate, and analyze the factors that influence the successful use of e-learning in the Faculty of Engineering. Respondent in this Research consisted of 330 people consisting of students and lecturers of the Faculty of Engineering who use e-learning. Sampling is done by accidental sampling method. The model used in the study is the successful model of Delone and McLean using descriptive analysis and Structural Equation Models (SEM) analysis using SMARTPLS 2.0. The results showed the high level of success in using e-learning at Engineering Faculty at Riau University in semantic succes level, then technical success level, and effectiveness success level. Factors that influencing the Engineering Faculty of Riau University are information quality and service quality.
\end{abstract}

Keywords: delon and mclean, e-learning, SEM, Faculty of Engineering University of Riau

\begin{abstract}
Abstrak: E-learning adalah sistem pembelajaran yang menggunakan sistem informasi dan teknologi internet atau intranet. E-learning merupakan salah satu alat pembelajaran di era revolusi teknologi 4.0 yang menjadi salah satu program dari Kementerian Riset Pendidikan Tinggi. Institusi pendidikan tinggi di Indonesia telah menggunakan e-learning dalam kegiatan pembelajaran. Penelitian ini bertujuan mengevaluasi keberhasilan, dan menganalisis faktor-faktor yang memengaruhi keberhasilan penggunaan e-learning di Fakultas Teknik Universitas Riau. Responden dalam penelitian terdiri dari 314 orang mahasiswa Fakultas Teknik yang menggunakan e-learning. Pengambilan sampel dilakukan dengan metode accidental sampling. Model yang digunakan dalam penelitian ini adalah model sukses Delone dan McLean. Analisis yang digunakan adalah analisis deskriptif dan analisis Structural Equation Model (SEM) menggunakan SMARTPLS 2.0. Hasil penelitian menunjukkan bahwa level keberhasilan tertinggi penggunaan e-learning Fakultas Teknik Universitas Riau adalah pada level keberhasilan semantik, kemudian level keberhasilan teknis dan level keberhasilan efektifitas. Faktor-faktor yang memengaruhi keberhasilan e-learning Fakultas Teknik Universitas Riau adalah kualitas informasi dan kualitas layanan.
\end{abstract}

Kata kunci: Delon dan McLean, e-learning, SEM, Fakultas Teknik Universitas Riau

\footnotetext{
${ }^{1}$ Alamat Korespondensi:

Email: neniselianaunri@gmail.com
} 


\section{PENDAHULUAN}

Perkembangan Teknologi Informasi (TI) yang pesat menyebabkan kebutuhan akan suatu konsep dan mekanisme belajar mengajar berbasis TI menjadi sangat penting. Perguruan Tinggi (PT) telah menggunakan TI untuk berbagai kegiatan diantaranya sebagai alat bantu kegiatan administrasi dan pendidikan (Raharjo, 2004). Komputer, data base, dan sistem informasi kemahasiswaan digunakan untuk membantu proses administrasi merupakan pemanfaatan TI dari sisi administrasi. Pemanfaatan TI dari sisi pendidikan, program komputer yang digunakan dosen untuk membantu dalam pemberian materi kuliah, nilai dan presentasi. Kusmana (2011) dalam disertasinya mengatakan bahwa e-learning menjadi kecenderungan dan pilihan karena adanya perubahan paradigma dunia pendidikan pada era globalisasi. E-learning dapat mengatasi keterbatasan antara pendidik dan peserta didik dalam hal ruang dan waktu. Penerapan e-learning menunjukkan adanya peningkatan hasil kompetensi, dan peningkatan pemahaman materi perkuliahan oleh mahasiswa (Lalpaka dan Kasma, 2017).

Demografi Negara Indonesia yang terdiri dari banyak pulau, merupakan salah satu kendala dalam pemerataan akses pendidikan. Penggunaan e-learning dapat menjadi solusi dari keterbatasan pembelajaran tatap muka. Merujuk kepada (Mendikbud, 2012), pemerintah melalui salah satu program Dirjen Pembelajaran dan Kemahasiswaan Kemristek Dikti, telah melaunching e-learning atau hybrid learning melalui Sistem Pembelajaran Daring (SPADA) Indonesia, merupakan peran serta pemerintah dalam mewujudkan pemerataan pendidikan. Penelitian pengembangan dalam pemanfaatan e-learning dalam pembelajaran yang telah dilakukan (Mu'arif dan Surjono, 2016; Helianak dan Surjono, 2014; Purmadi dan Surjono,
2016; Januarisman dan Ghufron, 2016; Supriyono dan Sugirin, 2014) menghasilkan peningkatan yang signifikan terhadap outcomes siswa, dibuktikan dengan peningkatan hasil belajar siswa. Penelitian lainnya tentang pengembangan aplikasi e-learning telah dilakukan Hartatik et al. (2018); Ariani (2018); Irawan dan Sarjono, (2018) mengembangkan aplikasi e-learning pada sekolah menengah atas, menghasilkan peningkatan pada hasil pembelajaran.

Perguruan tinggi di Indonesia telah melakukan pengembangan dan menerapkan e-learning sebagai sistem pembelajaran. Pengembangan e-learning pada perguruan tinggi dilakukan sesuai dengan keinginan dan kebutuhan masing-masing PT. Fakultas Teknik Universitas Riau (FT-UR) merupakan bagian dari perguruan tinggi di Indonesia yang telah menerapkan e-learning pada proses pembelajaran. Pembelajaran online (e-learning) di FT-UR menggunakan Learning Management System (LMS) pertama kali tahun 2008 dengan situs http://ft.unri.ac.id/lms/. Situs ini merupakan LMS yang dibangun menggunakan perangkat lunak bebas - Moodle. Keterbatasan sumberdaya dalam mengelola LMS menyebabkan LMS tidak berkembang dan LMS akhirnya tidak digunakan lagi. Pembelajaran online kembali diterapkan pada tahun 2014 dengan menggunakan salah satu aplikasi untuk pendidikan dari media online google, yaitu google classroom. Penggunaan media pembelajaran online Google classroom oleh dosen pada Fakultas Teknik UNRI sebagai sarana distribusi materi kuliah, tugas, pengumuman, kuis dan latihan soal. Penggunaan e-learning hanya berdasarkan pada kerelaan dosen, sehingga penggunaan tidak merata pada setiap jurusan yang ada di FT-UR. Sebaran penggunaan e-learning pada FT-UR untuk masing-masing jurusan ditunjukkan Gambar 1.

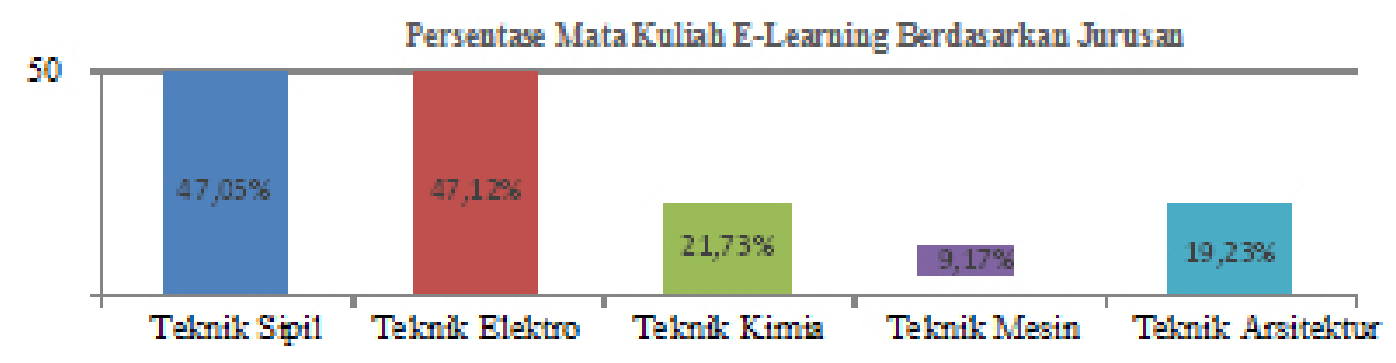

Gambar 1. Sebaran penggunaan e-learning berdasarkan jurusan di FT-UR 
Selama kurun waktu lima tahun penggunaane-learning di Fakultas Teknik Universitas Riau belum pernah dilakukan penelaahan bagaimana tingkat keberhasilan dari penerapan e-learning. Bagaimanakah keberhasilan penerapan e-learning, dan faktor-faktor apa saja yang memengaruhi keberhasilan penerapan e-learning di FTUR. Variabel yang akan diukur menggunakan model sukses keberhasilan Delone dan McLean Tahun 2013. Variabel yang diukur yaitu variabel kualitas informasi, kualitas sistem, kualitas layanan, penggunaan, kepuasan pengguna dan manfaat bersih yang diperoleh dari penggunaan e-learning FT-UR (Anggraini, 2016). Diperlukan evaluasi untuk mengukur keberhasilan dan kinerja dari suatu unit bisnis.

Sembilan hubungan antara variabel yaitu kualitas informasi dengan penggunaan, kualitas informasi dengan kepuasan pengguna, kualitas sistem dengan penggunaan, kualitas sistem dengan kepuasan penggunaan, kualitas layanan dengan penggunaan, kualitas layanan dengan kepuasan penggunaan. Hubungan penggunaan dengan kepuasan pengguna, penggunaan dengan manfaat bersih dan kepuasan pengguna terhadap manfaat bersih dari sistem. Penelitian telah dilakukan oleh Budiyanto (2009), Delone and McLean (2013), Sakkinah dan Fatmantara (2017), Ihsan M dan Azwar (2018), Yakudu dan Dasuki (2018). Tujuan dari penelitian, yaitu mengevaluasi tingkat keberhasilan, dan faktor-faktor apa saja yang memengaruhi keberhasilan penggunaan e-learning di FT-UR.

\section{METODE PENELITIAN}

Penelitian dilakukan pada kurun waktu Maret-Juni 2019, adapun lokasi penelitian bertempat di Fakultas Teknik Universitas Riau. Model yang digunakan adalah model Delone and McLean tahun 2013. Model ini adalah salah satu model yang digunakan untuk mengukur keberhasilan penggunaan sistem informasi. Model ini ditemukan oleh Delone and McLean pada tahun 1993 dan diperbaharui pada tahun 2013. Pengumpulan data dilakukan dengan menggunakan kuesioner. Pengisian kuesioner terdiri dari dua cara, yaitu diisi langsung oleh responden dan melalui google form. Data yang digunakan dalam penelitian adalah data primer dan data sekunder. Data primer adalah data utama yang diperoleh dari hasil pengisian kuesioner oleh responden. Data sekunder merupakan data pendukung yang diperoleh dari berbagai sumber penelitian, buku, jurnal, artikel, website internet, renstra FT-UR dan sumber-sumber yang terkait dengan penelitian. Kuesioner penelitian terdiri dari dua bagian, yaitu kuesioner perilaku responden dan kuesioner model. Kuesioner model menggunakan pertanyaan tertutup dengan skala Likert.

Pengisian kuesioner dilakukan dengan menyebarkan langsung kepada responden. Responden mengisi kuesioner dan memberikan penilaiannya berdasarkan persepsinya terhadap penerapan sistem e-learning di Fakultas Teknik Universitas Riau. Penilaian responden menggunakan skala angka 1 sampai 5 sesuai dengan pengalamanyang dirasakanrespondenterhadappenerapan e-learning di Fakultas Teknik. Kriteria penilaian yaitu: $1=$ Sangat tidak baik, $2=$ Kurang baik, $3=$ Cukup baik, 4= Baik, dan 5= Sangat baik. Populasi penelitian adalah mahasiswa Fakultas Teknik Universitas Riau. Populasi mahasiswa adalah mahasiswa aktif semester genap 2018/2019 yang menggunakan e-learning. Jumlah populasi mahasiswa sebanyak 3706. Penentuan jumlah sampel penelitian menggunakan rumus Slovin dengan taraf signifikasi $\alpha=0,10$, jumlah responden yang didapat sebanayak 315 orang selanjutnya digunakan sebagai sampel penelitian. Metode pengambilan sampel menggunakan probability sampling. Analisis data dibagi menjadi dua, yaitu analisis deskriptif menggunakan mean dan median, sedangkan analisis model menggunakan Structural Equation Modelling (SEM) PLS 2.0.

Penggunaan variabel dalam penelitian ini sesuai dengan pendekatan yang digunakan, yaitu model Delone dan McLean. Variabel-varibel tersebut dicari indikator yang memengaruhi masing-masing varibel. Indikator yang dipakai adalah indikator yang telah dibuktikan oleh peneliti-peneliti sebelumnya. Uraian lengkap variabel dan indikator sebagai berikut:

\section{Kualitas Informasi (information quality)}

Kualitas informasi dari penggunaan e-learning merupakan ukuran dari luaran dari e- learning yang digunakan oleh pengguna. Pada penelitian ini variabel kualitas informasi menggunakan delapan indikator sebagai berikut: kelengkapan (completeness), ditulis dengan jelas (clearly written), mudah dimengerti (easy of understanding), uptodate, akurat (accuracy), aman (security), relevan (relevance), berguna (useful). Penelitian terdahulu dilakukan oleh Delone dan McLean (2003); Livari (2005); Lee Post (2006); Gable et al. (2008). 


\section{Kualitas sistem (sistem quality)}

Kualitas sistem merupakan ukuran dari kualitas sistem informasi mencakup hardware dan software. Kualitas sistem adalah karakteristik bentuk keberhasilan yang diinginkan dari sebuah sistem informasi. Variabel kualitas sistem pada penelitian ini menggunakan tujuh indikator sebagai berikut: kemampuan adaptasi (adaptability), keandalan (reliability), waktu merespon (response time), mudah digunakan (easy to use). Penelitian terdahulu dilakukan oleh Delone dan McLean (2003), Gable et al. (2008).

\section{Kualitas pelayanan (service quality)}

Kualitas pelayanan merupakan rasio antara harapan dengan pelayanan yang diterima oleh pengguna. Kualitas layanan adalah bentuk keberhasilan dari kualitas layanan yang dirasakan oleh pengguna sistem informasi. Variabel kualitas layanan menurut Delone dan McLean (2003) terdiri dari tiga indikator, yaitu jaminan (assurance), empati (emphty), responsif (responsiveness).

\section{Penggunaan (used)}

Penggunaan yang dimaksud adalah penggunaan sistem informasi oleh pengguna, yang dilakukan secara sukarela. Penggunaan aktual dapat menjadi ukuran keberhasilan suatu sistem informasi. Variabel penggunaan menggunakan enam indikator sebagai berikut: Power point, audio/video, papan diskusi (discussion board), latihan soal (practice problem), tutorial excel (excel tutorials), tugas (assignment). Penelitian terdahulu dilakukan oleh Delone dan McLean (2003), Lee Post (2006).

\section{Kepuasan pengguna (user satisfaction)}

Kepuasan pengguna merupakan penilaian yang dirasakan oleh pengguna setelah menggunakan sistem informasi. Empat indikator digunakan untuk variabel kepuasan penggunaan yaitu: Kepuasan keseluruhan (overall satisfaction), pengalaman yang menyenangkan (enjoyble experience), menggunakan kembali (repeat visit).

\section{Hasil bersih yang diperoleh (net benefit)}

Hasil bersih yang diperoleh merupakan hasil atau keuntungan yang diperoleh individu dan organisasi setelah menggunakan sistem informasi. Variabel hasil bersih yang diperoleh pada penelitian ini menggunakan enam indikator peningkatan pembelajaran (Enhaced learning), pemberdayaan mahasiswa (empowerd), penghematan waktu (time saving), penghematan biaya (cost saving), keberhasilan akademik (academic success), keberhasilan keseluruhan (overall success). Penelitian terdahulu dilakukan oleh Delone dan McLean (2003), Lee Post (2006). Model Delone dan McLean pada penelitian ini digunakan sebagai dasar dan acuan dalam penyusunan kerangka pemikiran dalam mengukur keberhasilan penerapan e-learning di FT-UR. Kerangka pemikiran penelitian dijelaskan pada Gambar 2.

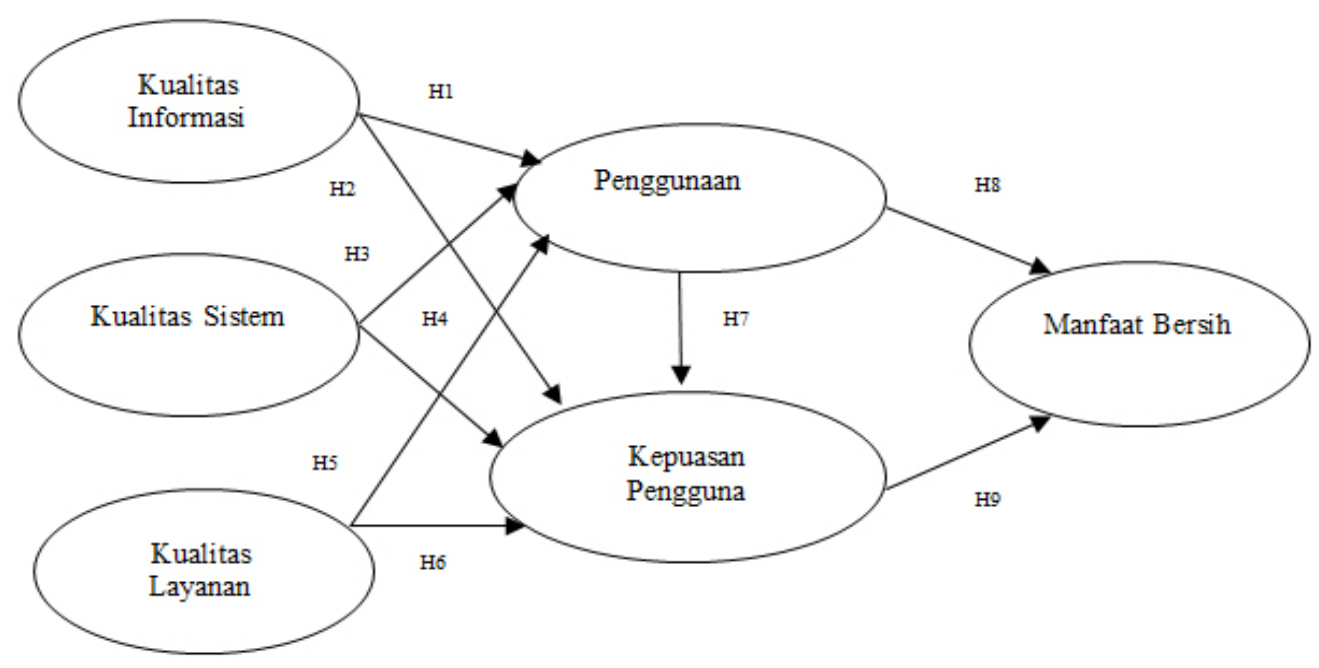

Gambar 2. Kerangka pemikiran penelitian 
Variabel terikat (Y) adalah penggunaan, kepuasan pengguna dan manfaat bersih. Variabel bebas (X) adalah kualitas informasi, kualitas sistem, dan kualitas layanan. Tiga indikator keberhasilan yang dapat diukur dengan model sukses Delone and McLean, yaitu 1). Kualitas sistem dan kualitas layanan digunakan untuk mengukur keberhasilan teknis. 2). Kualitas informasi digunakan untuk mengukur keberhasilan semantik. 3). Variabel pengunaan sistem, kepuasan pengguna, dan manfaat bersih dari sistem dapat digunakan untuk mengukur keberhasilan pelayanan dan efektifitas dari sistem.

\section{HASIL}

\section{Kondisi Keberhasilan E-learning pada Fakultas Teknik}

Kondisi keberhasilan penggunaan e-learning pada Fakultas Teknik merujuk kepada ukuran keberhasilan yang ditentukan pada model kesuksesan Delone and McLean. Tiga ukuran keberhasilan menurut Delone and McLean yaitu keberhasilan pada level teknis, diukur dari kualitas sistem dan kualitas layanan e-learning Fakultas Teknik Universitas Riau. Level semantik diukur dari kualitas informasi e-learning Fakultas Teknik Universitas Riau. Keberhasilan di level efektifitas dari sistem diukur melalui penggunaan sistem, kepuasan pengguna dan manfaat bersih yang diperoleh dari sistem e-learning Fakultas Teknik Universitas Riau.

Kondisi Keberhasilan E-learning pada Level Teknis dinilai dari Kualitas Sistem, Kualitas Layanan, dan pada Level Semantik dinilai dari Kualitas Informasi

Kondisi keberhasilan penggunaan e-learning di Fakultas Teknik Universitas Riau pada level teknis dinilai dari kualitas sistem dan kualitas layanan, dan keberhasilan pada level semantik dinilai dari kualitas informasi ditunjukkan pada Tabel 1. Kualitas sistem dari penggunaan e-learning di Fakultas Teknik Universitas Riau secara keseluruhan berkinerja baik dengan nilai total keseluruhan indikator masing- masing 3,93. Kualitas layanan dari penggunaan e-learning di Fakultas Teknik Universitas Riau secara keseluruhan berkinerja baik.

Level keberhasilan teknis meliputi variabel kualitas sistem dengan indikator kemampuan adaptasi, keandalan, waktu respon, dan mudah digunakan. Mudah digunakan merupakan indikator tertinggi, selanjutnya kemampuan adaptasi, dan keandalan. Waktu respon merupakan indikator terendah. Secara keseluruhan kondisi kinerja dari kualitas sistem ditunjukkan Gambar 2.

Tabel 1. Kondisi keberhasilan e-learning pada level teknis dinilai dari kualitas sistem, kualitas layanan, dan pada level semantik dinilai dari kualitas informasi

\begin{tabular}{clccc}
\hline Variabel & \multicolumn{1}{c}{ Indikator } & Simbol & Mean & Median \\
\hline Kualitas Informasi & Kelengkapan & KI1 & 3,77 & 4,00 \\
& Ditulis dengan jelas & KI2 & 3,79 & 4,00 \\
& Mudah dimengerti & KI3 & 3,96 & 4,00 \\
& Uptodate & KI4 & 3,77 & 4,00 \\
& Akurat & KI5 & 3,89 & 4,00 \\
& Aman & KI6 & 3,92 & 4,00 \\
& Relevan & KI7 & 4,00 & 4,00 \\
& Berguna & KI8 & 4,18 & 4,00 \\
& & Total & 3,91 & 4,00 \\
Kualitas Sistem & KS1 & 3,98 & 4,00 \\
& Kemampuan adaptasi & KS2 & 3,89 & 4,00 \\
& Keandalan & KS3 & 3,78 & 4,00 \\
& Waktu respon & KS4 & 4,08 & 4,00 \\
& Mudah digunakan & Total & 3,93 & 4,00 \\
& & KL1 & 3,83 & 4,00 \\
Kualitas Layanan & Jaminan & KL2 & 3,61 & 4,00 \\
& Perhatian & Total & 3,62 & 4,00 \\
& Responsiveness & 3,69 & 4,00 \\
\hline \hline
\end{tabular}


Level keberhasilan teknis berdasarkan variabel kualitas layanan dengan indikator jaminan, perhatian dan responsiveness. Jaminan merupakan indikator tertinggi, selanjutnya berturut-turut perhatian dan responsiveness. Kinerja kualitas layanan dari e-learning secara keseluruhan bernilai baik seperti Gambar 3.

Keberhasilan level semantik ditinjau dari sisi kualitas informasi penerapan e-learning secara keseluruhan seperti pada Tabel 2 berkinerja tinggi. Dua dari delapan indikator pembentuk kualitas informasi berkontribusi paling besar terhadap pembentuk kualitas informasi yaitu berguna dan relevan. Apabila diurutkan indikator pembentuk kualitas layanan mulai dari nilai tertinggi yaitu berguna, relevan, mudah dimengerti, aman, akurat, ditulis dengan jelas, kelengkapan, dan uptodate. Dengan demikian, dapat disimpulkan bahwa penggunaan e-learning di Fakultas Teknik Universitas Riau pada level keberhasilan semantik tinggi. Kondisi kinerja keseluruhan dari kualitas informasi e-learning di Fakultas Teknik Universitas Riau seperti pada Gambar 4.

Kondisi Keberhasilan pada Level Efektifitas Sistem E-learning Fakultas Teknik Universitas Riau

Kondisi keberhasilan level efektivitas sistem e-learning Fakultas Teknik Universitas Riau ditinjau dari penggunaan, kepuasan pengguna terhadap sistem dan manfaat bersih system e-learning ditunjukkan oleh Tabel 2. Hasil penelitian menunjukkan dua indikator variabel penggunaan, yaitu powerpoint dan tugas merupakan indikator terbaik dari indikator pembentuk penggunaan. Indikator forum diskusi merupakan indikator yang berkontribusi paling rendah terhadap penggunaan. Apabila diurutkan berdasarkan nilai tertinggi dari penggunaan e-learning adalah powerpoint, tugas, audio/video, tutorial excel, latihan soal dan forum diskusi. Kepuasan pengguna rata-rata berkinerja tinggi. Indikator keinginan menggunakan kembali berkontribusi paling tinggi terhadap kepuasan pengguna. Penilaian terhadap manfaat bersih secara keseluruhan dari sistem berkinerja sangat tinggi. Indikator dengan nilai tertinggi yaitu keberhasilan akademik dan indikator hemat waktu. Pemberdayaan merupakan indikator yang paling rendah kontribusinya terhadap manfaat bersih sistem e-learning.

Kondisi keberhasilan penggunaan e-learning di Fakultas Teknik secara keseluruhan disimpulkan berkinerja tinggi. Keberhasilan tertinggi yaitu keberhasilan pada level semantik, selanjutnya keberhasilan level teknis, dan keberhasilan pada level efektivitas. Keberhasilan penggunaan e-learning pada Fakultas Teknik ditunjukkan pada Gambar 5.

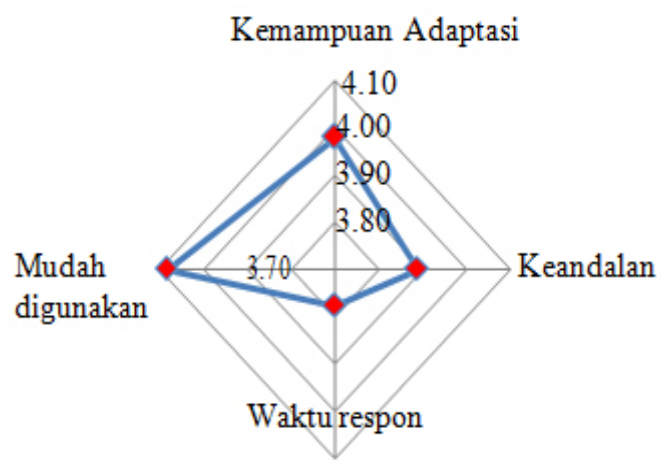

Gambar 2. Kinerja kualitas sistem e-learning

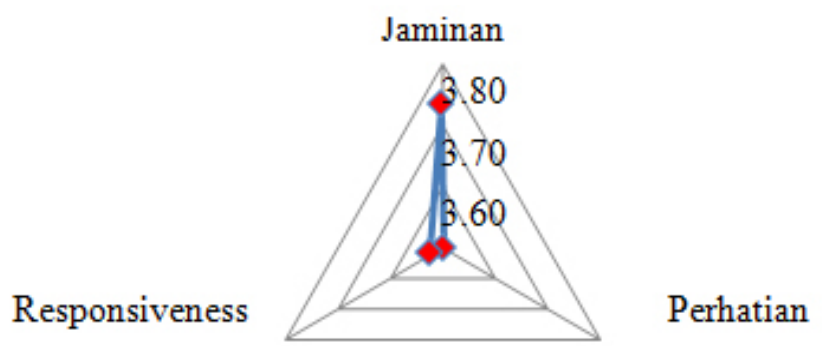

Gambar 3. Kinerja kualitas layanan e-learning

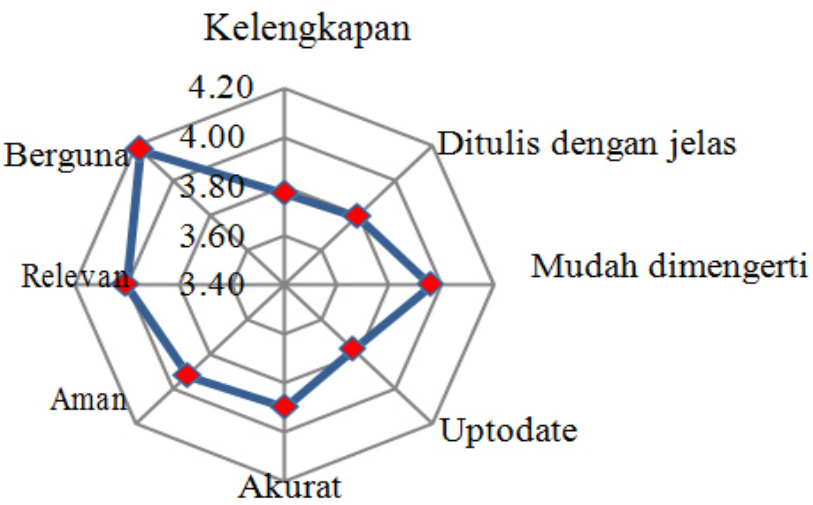

Gambar 4. Kinerja kualitas informasi e-learning

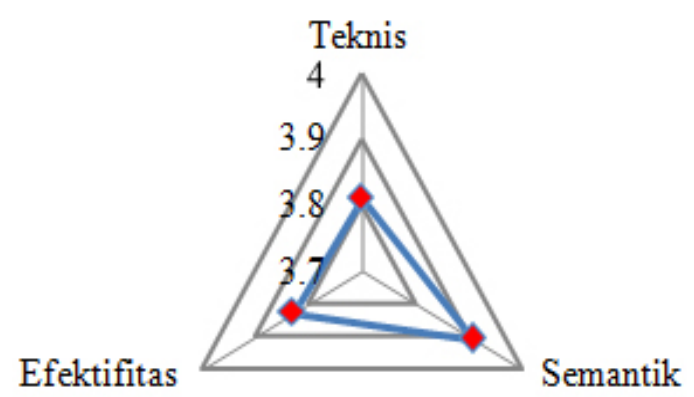

Gambar 5. Kondisi keberhasilan penerapan e-learning 
Tabel 2. Penilaian keberhasilan penggunaan e-learning pada level efektifitas

\begin{tabular}{clccc}
\hline Variabel & Indikator & Simbol & Mean & Median \\
\hline Penggunaan & Power point & P1 & 4,04 & 4,00 \\
& Audio/Video & P2 & 3,74 & 4,00 \\
& Forum diskusi & P3 & 3,39 & 3,00 \\
& Latihan soal & P4 & 3,60 & 4,00 \\
& Toturial excel & P5 & 3,72 & 4,00 \\
& Tugas & P6 & 4,00 & 4,00 \\
& & Total & 3,75 & 4,00 \\
Kepuasan Pengguna & Kepuasan keseluruhan & KP1 & 3,81 & 4,00 \\
& Pengalaman yang menyenangkan & KP2 & 3,76 & 4,00 \\
& Keinginan menggunakan kembali & KP3 & 3,85 & 4,00 \\
& & Total & 3,81 & 4,00 \\
Manfaat Bersih & MB1 & 3,84 & 4.00 \\
& Peningkatan kemampuan & MB2 & 3,73 & 4,00 \\
& Pemberdayaan & MB3 & 4,16 & 4,00 \\
& Hemat waktu & MB4 & 3,88 & 4,00 \\
& Hemat biaya & MB5 & 4,22 & 4,00 \\
& Keberhasilan akademik & MB6 & 3,89 & 4,00 \\
& Keberhasilan keseluruhan & Total & 3,95 & 4,00 \\
\hline
\end{tabular}

\section{Pengujian Hipotesis}

Pengujian setiap hubungan (hipotesis) pada penelitian dilakukan dengan menggunakan bootstrapping terhadap sampel. Pengujian hipotesis dengan melihat hasil nilai $\mathrm{t}$ statistik pada taraf $5 \%$. Apabila nilai t statistik lebih besar dari nilai $t$ tabel, yaitu 1,96 maka hipotesis diterima atau berpengaruh signifikan. Pengujian hipotesis juga dapat dilakukan dengan melihat nilai Koefisien Jalur (path coefficient). Hasil hipotesis penelitian ditunjukkan pada Tabel 3 .

Berdasarkan Tabel 3 nilai t-statistik hasil penelitian menunjukkan tujuh dari sembilan hubungan antara variabel dan indikator signifikan bernilai 2,126 sampai 11,847 . Terdapat dua indikator yang tidak signifikan yaitu kualitas layanan terhadap kepuasan pengguna dan kualitas sistem terhadap penggunaan dengan nilai 0,855 dan 1,398 . Kualitas layanan berpengaruh sangat signifikan dengan nilai T-statistik 11,847. Dua hipotesis yang dinyatakan tidak signifikan adalah kualitas sistem terhadap penggunaan dan kualitas layanan terhadap kepuasan pengguna dengan nilai T-statistik kurang dari 1,96. Hasil t-statistik model struktural ditunjukkan pada Gambar 6.
Pengaruh Kualitas Informasi, Kualitas Sistem dan Kualitas Layanan terhadap Penggunaan E-learning Fakultas Teknik Universitas Riau

Kualitas informasi berpengaruh signifikan sedangkan kualitas layanan berpengaruh sangat signifikan terhadap penggunaan e-learning di Fakultas Teknik Universitas Riau. Hasil ini mendukung teori Delone and McLean, dan sesuai dengan penelitian Trihandayani et al. (2018). Namun demikian, dalam penelitian ini menunjukkan kualitas sistem tidak memberikan pengaruh yang signifikan terhadap penggunaan. Hasil ini menunjukkan bahwa semakin tinggi tingkat kualitas sistem berupa kemampuan adaptasi, keandalan, kecepatan respon dan mudah digunakan belum mampu meningkatkan penggunaan e-learning. Hasil hipotesis didukung oleh penelitian Ikhsan et al. (2018). Disarankan bila Fakultas Teknik hendak peningkatan penggunaan e-learning, upaya dapat dilakukan pada peningkatan kualitas layanan dan kualitas informasi. Prioritas utama dalam perbaikan tinggkat penggunaan e-learning dapat dilakukan dengan upaya yang serius dalam peningkatan kualitas layanan. Hal ini karena kualitas layanan mempunyai direct effect yang lebih tinggi terhadap penggunaan dibandingkan dengan kualitas informasi terhadap penggunaan e-learning di Fakultas Teknik. Prioritas berikutnya dalam upaya peningkatan penggunaan e-learning di Fakultas Teknik dapat dilakukan melalui perbaikan kualitas informasi. 
Tabel 3. Ringkasan Model Struktural (hasil hipotesis)

\begin{tabular}{lcccc}
\hline \multicolumn{1}{c}{ Hubungan antara indikator dan variabel } & Hipotesis & Path coefficient & T-statistik & Keterangan \\
\hline Kualitas Informasi $\rightarrow$ Penggunaan & H1 & 0,261 & $4,039^{*}$ & Signifikan \\
Kualitas Sistem $\rightarrow$ Penggunaan & H2 & 0,061 & 1,398 & Tidak Signifikan \\
Kualitas Layanan $\rightarrow$ Penggunaan & H3 & 0,570 & $11,847^{*}$ & Signifikan \\
Kualitas Informasi $\rightarrow$ Kepuasan Pengguna & H4 & 0,161 & $2,126^{*}$ & Signifikan \\
Kualitas Sistem $\rightarrow$ Kepuasan Pengguna & H5 & 0,162 & $2,701^{*}$ & Signifikan \\
Kualitas Layanan $\rightarrow$ Kepuasan Pengguna & H6 & 0,049 & 0,855 & TidakSignifikan \\
Penggunaan $\rightarrow$ Kepuasan Pengguna & H7 & 0,524 & $5,954^{*}$ & Signifikan \\
Penggunaan $\rightarrow$ Manfaat Bersih & H8 & 0,492 & $8,567^{*}$ & Signifikan \\
Kepuasan Pengguna $\rightarrow$ Manfaat Bersih & H9 & 0,427 & $7,368^{*}$ & Signifikan \\
\hline
\end{tabular}

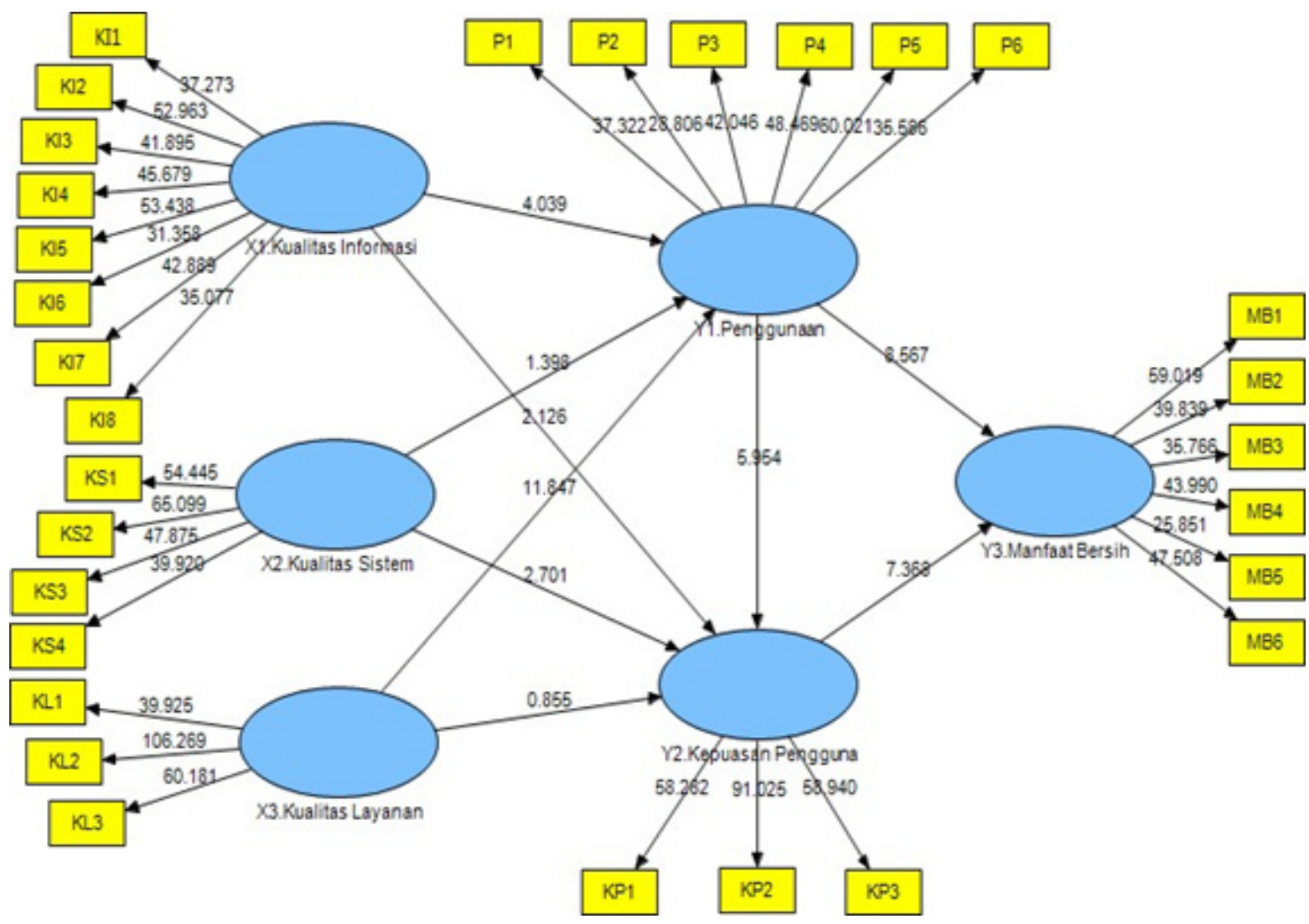

Gambar 6. Model struktural

Pengaruh Kualitas Informasi, Kualitas Sistem dan Kualitas Layanan terhadap Kepuasan Pengguna E-learning Fakultas Teknik Universitas Riau

Kualitas informasi dan kualitas sistem berpengaruh signifikan terhadap kepuasan pengguna. Hal ini mendukung model penelitian Delone and McLean. Kualitas layanan tidak memberikan pengaruh yang signifikanterhadapkepuasan penggunae-learning. Hasil penelitian menunjukkan peningkatan kualitas layanan berupa jaminan, perhatian dan responsiveness belum mampu meningkatkan kepuasan pengguna e-learning. Hasil analisis tidak mendukung penelitian Delone and
McLean. Hasil hipotesis didukung oleh penelitian Tan et al. (2015); Hudin et al. (2016). Dari kedua variabel yang berpengaruh signifikan, kualitas sistem memiliki direct effect yang lebih tinggi dibandingkan kualitas informasi. Sehingga bila Fakultas Teknik hendak memperbaiki kinerja kepuasan pengguna darie-learning dapat secara langsung melakukan peningkatan kualitas sistem terlebih dahulu, kemudian peningkatan kualitas informasi. Aspek keandalan dan kemampuan adaptasi dari kualitas sistem mempunyai nilai loading factor yang tinggi. Hal ini menjadi peluang untuk peningkatan kepuasan pengguna pada sistem e-learning. 
Secara tidak langsung, kepuasan pengguna e-learning di Fakultas Teknik dapat juga ditingkatkan dengan perbaikan pada dua variabel tersebut (indirect effect), melalui variabel penggunaan. Perbaikan melalui jalur tidak langsung melalui variabel penggunaan ini yang paling tinggi adalah yang melalui jalur perbaikan kualitas layanan $\rightarrow$ penggunaan $\rightarrow$ kepuasan pengguna, disusul dengan kualitas informasi $\rightarrow$ penggunaan $\rightarrow$ kepuasan pengguna.

Hubungan antara Penggunaan, Kepuasan Pengguna dengan Manfaat Bersih penerapan E-learning Fakultas Teknik Universitas Riau

Terdapat pengaruh positif yang signifikan antara variabel penggunaan dengan manfaat bersih dari penggunaan e-learning di Fakultas Teknik Universitas Riau. Hal yang sama juga terjadi pada variabel kepuasan pengguna terhadap manfaat bersih dari penggunaan e-learning di Fakultas Teknik Universitas Riau. Perbaikan tingkat keberhasilan bersih dari penggunaan e-learning di Fakultas Teknik Universitas Riau, prioritas utamanya adalah melalui upaya peningkatan terhadap penggunaan sistem kemudian diikuti dengan upaya peningkatan kepuasan dari pengguna.

Upaya lain juga dapat dilakukan dengan peningkatan kepuasan pengguna melalui peningkatan penggunaan terhadap sistem e-learning di Fakultas Teknik Universitas Riau. Hal ini juga dapat dilihat dari besaran total effect dari penggunaan terhadap manfaat bersih menunjukkan nilai tertinggi. Total effect penggunaan terhadap keberhasilan e-learning Fakultas Teknik Universitas Riau adalah direct effect dari penggunaan terhadap tingkat keberhasilan manfaat bersih ditambah indirecteffect penggunaanterhadap tingkatkeberhasilan manfaat bersih melalui kepuasan pengguna. Nilai indirect effect dari penggunaan terhadap tingkat keberhasilan manfaat bersih diperoleh dari perkalian nilai direct effect penggunaan $\rightarrow$ kepuasan pengguna dengan nilai direct effect dari kepuasan penguna $\rightarrow$ manfaat bersih.

\section{Implikasi Manajerial}

Hasil penelitian menunjukkan bahwa penggunaan e-learning di FT-UR untuk keberhasilan pada level teknis dinilai telah baik. Merujuk hubungan antara nilai faktor loading dengan aktual penggunaan e-learning (Gambar 7), disarankan untuk dipertahankan dan ditingkatkan menjadi lebih baik lagi. Saran perbaikan untuk peningkatan keberhasilan pada level keberhasilan teknis dapat dilakukan dengan memperbaiki indikatorindikator pembentuk kualitas sistem dan kualitas layanan. Upaya perbaikan pada kualitas sistem untuk kategori mahasiswa adalah dengan peningkatan pada indikator waktu respon dan kategori dosen adalah dengan peningkatan indikator kemampuan adaptasi, waktu respon dan keandalan. Perbaikan pada kualitas layanan untuk kategori mahasiswa dapat dilakukan dengan meningkatkan kinerja indikator-indikator kualitas pelayanan berturut-turut yaitu perhatian, dan responsiveness.

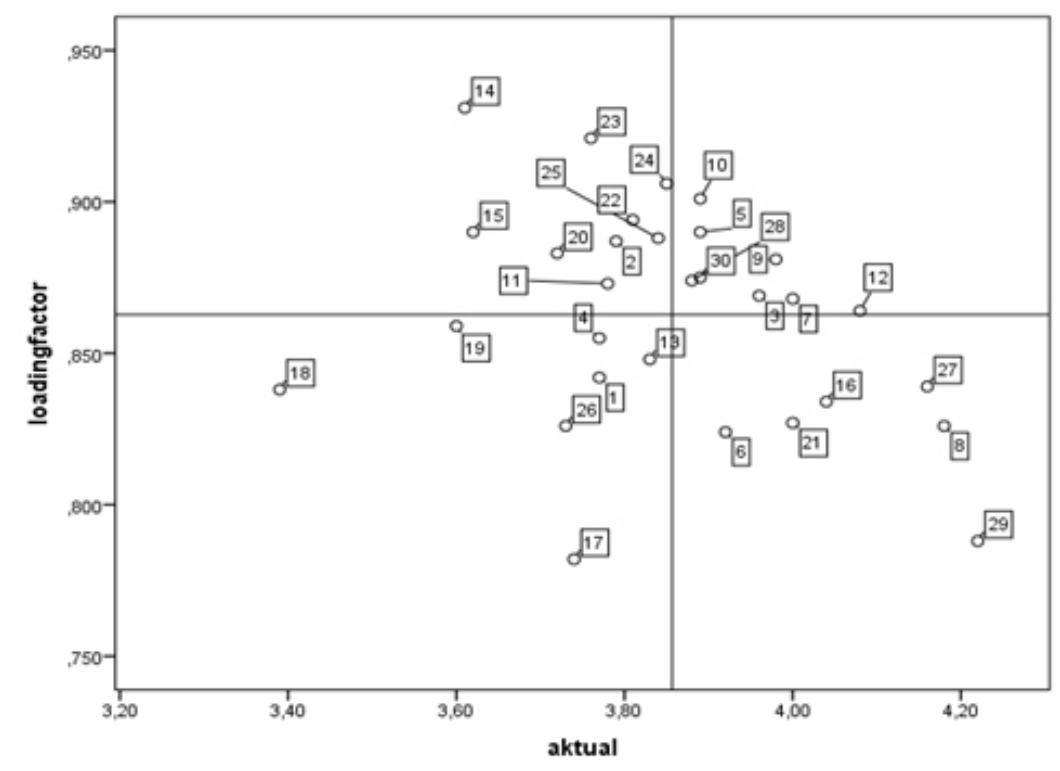

Gambar 7. Hubungan antara loading factor dengan aktual penggunaan e-learning FT-UR 


\section{KESIMPULAN DAN SARAN}

\section{Kesimpulan}

Dari kondisi analisis keberhasilan penggunaan e-learning di Fakultas Teknik Universitas Riau pada semua level keberhasilan adalah baik. Keberhasilan pada level semantik merupakan keberhasilan tertinggi, selanjutnya keberhasilan pada level efektifitas, dan keberhasilan level teknis.

Keberhasilan penggunaan e-learning mulai dari level keberhasilan teknis, semantik dan efektifitas pada Fakultas Teknik Universitas Riau dipengaruhi oleh faktor-faktor penentu antara lain, level keberhasilan teknis dipengaruhi oleh kualitas sistem dan layanan. Sedangkan keberhasilan pada level semantik dipengaruhi oleh kualitas informasi sistem e-learning di Fakultas Teknik Universitas Riau dipengaruhi oleh indikator-indikator pembentuk kualitas informasi. Adapun keberhasilan pada level efektifitas dipengaruhi oleh penggunaan sistem, kepuasan penguna terhadap sistem dan manfaat bersih dari sistem. Keberhasilan penggunaan pada e-learning di Fakultas Teknik dipengaruhi kualitas informasi dan kualitas layanan. Sedangkan keberhasilan kepuasan pengguna terhadap sistem dipengaruhi oleh kualitas informasi, kualitas sistem dan penggunaan. Selanjutnya, keberhasilan dari manfaat bersih dipengaruhi oleh penggunaan sistem dan kepuasan pengguna terhadap sistem e-learning Fakultas Teknik Universitas Riau. Keberhasilan dari manfaat bersih juga dipengaruhi oleh indikatorindikatorpembentuknya antara lain penghematan waktu, penghematan biaya, terjadi peningkatan pembelajaran, pemberdayaan terhadap kemampuan, keberhasilan akademik, dan anggapan sukses keseluruhan dari sistem. Faktor yang memengaruhi secara tidak langsung adalah penggunaan, kualitas sistem, kualitas informasi dan kualitas layanan.

\section{Saran}

Penelitian selanjutnya disarankan untuk pengambilan data tidak hanya pada fakultas tertentu tetapi seluruh fakultas yang ada di Universitas Riau. Saran selanjutnya adalah menambahkan lebih banyak indikator pembentuk pada masing-masing variabel penelitian.

\section{DAFTAR PUSTAKA}

Anggraini IR, Hubies VA, Tampubolon J. 2016. Evaluasi kinerja unit bisnis asphalt mixing plant pt prayoga pertambangan dan energi. Jurnal Aplikasi Bisnis dan Manajemen (JABM) 2(2).

Ariana D. 2018. Komponen pengembangan e-learning. Jurnal Prodi Teknologi Pendidikan FIP UNJ 1(1) (2018):58-64

DeLone, McLean 2003. The delone and mclean model of information system succes: a ten-year update. Journal of Management Information System/ Spring 19(4):9-30.

Ghozali, Latan. 2012 Partial Least Square Konsep, Teknik dan Aplikasi SmartPLS2.0M3. Semarang: Badan Penerbit Universitas Diponegoro

Hartatik et al. 2017. Pengembangan apilkasi e-learning sekolah menengah atas. Jurnal Simetris 8(2).

Helianak AS, Surjono HD. 2014. Pengembangan e-learning mata pelajaran teknologi informasi dan komunikasi (tik) di SMA Negeri 3 Kupang. Jurnal Inovasi Teknologi Pendidikan1(1): 1-14

Hudin MH, Riana D. 2016. Kajian keberhasilan penggunaan sistem informasi accurate dengan menggunakan model kesuksesan sistem informasi delon dan mclean. Jurnal Sistem Informasi (Journal of Information Systems) 1/12 (2016): 1-8. http://dx.doi.org/10.21609/jsi. v12i1.444

Ikhsan AR, Azwar. 2018. Analisis faktor-faktor yang mempengaruhi kesuksesan implementasi sistem e-filing pajak: studi kasus Kantor Pelayanan Pajak Madya Makasar. Jurnal BPPK 11(2):1234.

Irawan R, Surjono DH. 2018. Pengembangan e-learning berbasis moodle dalam peningkatan pemahaman lagu pada pembelajaran Bahasa Inggris. Jurnal Inovasi Pendidikan 5(1):1-11.

Januarisman E, Ghufron A. 2016. Pengembangan media pembelajaran berbasis web mata pelajaran ilmu pengetahuan alam siswa kelas VII. Jurnal Inovasi Teknologi Pendidikan 3(2): 167-182.

Kusmana. 2011. E-Learning dalam pembelajaran. Lentera Pendidikan 14(1):35-51 